\title{
NMDA Receptor Blockade Rescues Clarke's and Red Nucleus Neurons after Spinal Hemisection
}

\author{
Cynthia A. Sanner, ${ }^{1}$ Timothy J. Cunningham, ${ }^{2}$ and Michael E. Goldberger ${ }^{2}$ \\ 'Department of Neurology, Washington University School of Medicine, St. Louis, Missouri 63110 and ${ }^{2}$ Department of \\ Anatomy and Neurobiology, Medical College of Pennsylvania, Philadelphia, Pennsylvania 19129
}

Hemisection of the adult rat spinal cord at $T_{9}$ transects the ascending ipsilateral axons of Clarke's nucleus (CN) neurons and the descending contralateral axons of red nucleus (RN) neurons. Eight weeks following axotomy, $30 \%$ of $\mathrm{CN}$ neurons and $22 \%$ of RN neurons die. Since both nuclei receive glutamatergic input, we wished to examine the possibility that glutamatergic excitotoxicity contributes to axotomy-induced neuronal death in these nuclei. To test this we studied the effects of administration of the NMDA receptor antagonist MK-801 on cell survival after axotomy. When 1 $\mathrm{mg} / \mathrm{kg}$ body weight MK-801 is administered subcutaneously every day for 1-8 weeks to hemisected rats, cell death is prevented. Treatment with $0.5 \mathrm{mg} / \mathrm{kg}$ body weight MK-801 over the same time periods results in only partial rescue of axotomized neurons. Paradoxically, when $1 \mathrm{mg} / \mathrm{kg}$ MK-801 administration is restricted to the first week of an 8 week survival period, cell death in both the RN and $\mathrm{CN}$ is greatly exaggerated over the cell loss found in saline-treated animals. Withdrawal of $1 \mathrm{mg} / \mathrm{kg}$ MK-801 after 1 week of administration induces the loss of $92 \%$ of $\mathrm{CN}$ neurons, which is $63 \%$ greater than that occurring after axotomy alone. If, however, $1 \mathrm{mg} / \mathrm{kg}$ MK-801 is withdrawn after 2 weeks postaxotomy in the RN and 3 weeks postaxotomy in $\mathrm{CN}$, all axotomized neurons survive. This rescue is found at 6 months postsurgery, the longest survival period studied, and therefore appears to be permanent. These results suggest that glutamatergic afferent input contributes significantly to the death of axotomized red nucleus and Clarke's nucleus neurons via NMDA receptors located on these neurons.

[Key words: MK-801, axotomy, retrograde cell death, NMDA receptors, Clarke's nucleus, Red nucleus]

Recovery of function after damage to the CNS can be correlated with the extent of neuronal survival following injury (Eidelberg et al., 1977; Goldberger, 1980; Janssen and Hansebout, 1989). One approach for enhancing neuronal survival following a CNS injury is blockade of the neurotoxic actions of glutamate or other

Received Sept. 7, 1993; revised Apr. 5, 1994; accepted Apr. 21, 1994.

We thank Drs. D. Faber, M. Nowycky, M. Murray, A. Tessler, and E. H. Murphy for their comments and review of the manuscript, and Merck Sharp \& Dohme Research Labs, P.O. Box 2000; Rahway, NJ, for their generous donation of the MK-801. This work was supported by NIH Grant NS24707 and NS16487 (T.J.C.)

Correspondence should be addressed to Cynthia A. Sanner, Department of Neurology, Washington University, Box 8111,660 South Euclid Street, St. Louis, MO 63110.

Copyright (C) 1994 Society for Neuroscience $0270-6474 / 94 / 146472-09 \$ 05.00 / 0$ excitatory amino acids. For example, antagonists to the NMDA subtype of glutamate receptor inhibit excitotoxic cell death after ischemic insults (Simon et al., 1984; Weiss et al., 1986; Faden et al., 1988), epileptic seizures or kindling (Collins and Olney, 1982; Croucher et al., 1988; Gilbert, 1988; Clifford et al., 1989), and trauma (Faden and Simon, 1988; Gomez-Pinilla et al., 1989; Tecoma et al., 1989). All of these studies are concerned with excitotoxic cell death in the vicinity of the original insult. There can, however, be repercussions at sites distant to an injury, including retrograde cell death of neuron populations that send their axons through the damaged region. In a previous study, we demonstrated that axotomy-induced cell death in the Clarke's nucleus of cats is prevented if the neurons are deafferented prior to the axotomy (Sanner et al., 1993). One explanation for these results is that the dorsal root afferents that are glutamatergic are toxic to neurons that have been compromised by axotomy. As is the case for locally injured neurons, this toxicity to $\mathrm{CN}$ neurons may be mediated through the NMDA receptor subtype of glutamate receptor. The purpose of this study is to test this idea experimentally by administration of MK-801, a noncompetitive NMDA receptor antagonist (Wong et al., 1986; Kemp et al., 1987; Willetts et al., 1990) to rats whose spinal cords have been hemisected. We have therefore determined the effect of NMDA receptor blockade on axotomy-induced cell death in two nuclei, Clarke's nucleus of the spinal cord and the red nucleus of the midbrain.

Clarke's nucleus (CN) is a bilateral spinal cord nucleus containing neurons whose axons ascend within the dorsal spinocerebellar tract (DSCT) to the ipsilateral cerebellum. The majority of afferent input is from dorsal roots (Mann, 1973; Walmsley, 1991) and is in part glutamatergic (Maxwell et al., 1990). The red nucleus (RN) is a bilateral nucleus located in the midbrain, and its axons descend ipsilaterally to the inferior olive as well as contralaterally within the rubrospinal tract (RST) to the brainstem and the spinal cord. The RN receives the majority of its afferent input from the cerebral cortex, which is glutamatergic (Bernays et al., 1988; Nieoullon et al., 1988). There are also projections from the deep nuclei of the cerebellum (Holselge and Tan, 1988), some of which are glutamatergic (Nieoullon et al., 1988; Benson et al., 1991) and others cholinergic (Nieoullon et al., 1981). Fibers of both the RST and DSCT course in the lateral funiculus of the spinal cord, so a lateral funiculotomy will simultaneously axotomize neurons in the ipsilatcral $\mathrm{CN}$ and the contralateral magnocellular region of the RN.

The results of this study demonstrate that endogenous glutamatergic input contributes significantly to the retrograde cell 
Table 1. Means of neuron counts from unoperated (Normal), and the control sides of saline-treated (Sal), $1 \mathrm{mg} / \mathrm{kg}$ (1MG), and $0.5 \mathrm{mg} / \mathrm{kg}$ (0.5MG) experimental CN and RN, \pm SEM

Number of Red Nucleus Neurons

Number of Clarke's Neurons at $\mathrm{L}_{1}$

\begin{tabular}{|c|c|c|c|c|c|c|}
\hline \multirow[b]{2}{*}{ Animals } & \multirow[b]{2}{*}{$n$} & \multicolumn{3}{|c|}{ Number of Clarke's Neurons at $\mathrm{L}_{1}$} & \multirow[b]{2}{*}{ Control cell counts } & \multirow{2}{*}{$\begin{array}{l}\text { \# Neurons } \\
\text { per } \\
\text { section }\end{array}$} \\
\hline & & \# sections & Control cell counts & $\begin{array}{l}\text { \# Neurons per } \\
\text { section }\end{array}$ & & \\
\hline Normal & 5 & $16.0 \pm 0.0$ & $395.2 \pm 15.9$ & 24.7 & $1561.6 \pm 92.1$ & 97.6 \\
\hline \multicolumn{7}{|c|}{ 1st experimental group } \\
\hline Sal & 5 & $15.4 \pm 1.91$ & $370.2 \pm 80.6$ & 24.0 & $1575.0 \pm 210.4$ & 102.3 \\
\hline $1 \mathrm{MG}$ & 15 & $18.27 \pm 0.94$ & $451.27 \pm 30.37$ & 24.6 & $1623.47 \pm 58.19$ & 88.86 \\
\hline $0.5 \mathrm{MG}$ & 10 & $15.9 \pm 1.35$ & $438.6 \pm 52.18$ & 26.3 & $1604.0 \pm 102.76$ & 100.9 \\
\hline \multicolumn{7}{|c|}{ 2nd Experimental group } \\
\hline Sal & 4 & $18.0 \pm 1.08$ & $422.5 \pm 45.8$ & 23.3 & $1726.2 \pm 143.6$ & 95.9 \\
\hline $1 \mathrm{MG}$ & 12 & $18.58 \pm 0.6$ & $484.38 \pm 31.66$ & 26.1 & $1792.9 \pm 62.0$ & 96.5 \\
\hline $0.5 \mathrm{MG}$ & 8 & $19.0 \pm 0.57$ & $448.06 \pm 24.62$ & 23.6 & $1913.06 \pm 116.7$ & 100.7 \\
\hline
\end{tabular}

Number of neurons per section is not significantly different between control nuclei of experimental animals and normal nuclei.

death of $\mathrm{CN}$ and RN neurons after axotomy since blockade of NMDA receptors with MK-801 completely inhibits cell death in both populations. Prevention of cell death is dependent on MK-801 dosage and the timing of administration.

\section{Materials and Methods}

Animals. Eighty-five female Sprague-Dawley rats (Zivic-Miller, Allison Park, PA) (60-150 d of age, 250-400 gm at time of surgery) were deeply anesthetized with an intraperitoneal injection consisting of $x y l a z i n e(10$ $\mathrm{mg} / \mathrm{kg})$, ketamine $(95 \mathrm{mg} / \mathrm{kg})$, and acepromazine maleate $(0.7 \mathrm{mg} / \mathrm{kg})$ prior to surgery. Prior to perfusion all animals were deeply anesthetized with an overdose of sodium pentobarbital (Nembutal, $75 \mathrm{mg} / \mathrm{kg}$, i.p.).

Normals. Five unoperated animals were used to determine the normal number of neurons that comprise both right and left Clarke's nuclei at $\mathbf{L}_{1}$ and the right and left magnocellular portion of the red nucleus.

Surgery. Following NIH animal care guidelines, all animals received a right lateral funiculotomy at $T_{9}$ under aseptic conditions. The spinal cord of each animal was exposed by dorsal laminectomy of spinal segments $T_{8}-T_{9}$, just caudal to the dorsal fat pad. The dura was opened at the midline, and the right lateral funiculus was cut with iris surgical scissors. The lesion completely transected the lateral funiculus, including the DSCT and the RST.

Schedule of treatments. Immediately following their hemisection, all treated animals began receiving daily injections of either $0.5 \mathrm{mg} / \mathrm{kg}$ or $1 \mathrm{mg} / \mathrm{kg}$ body weight MK-801 in a $3 \mathrm{cc}$ saline vehicle. Control animals were also hemisected, but received daily injections of $3 \mathrm{cc}$ sterile saline alone. Animals were then assigned to one of two experimental groups. The first experimental group was used to determine the time course and dosage effects of MK-801 administration by sacrificing animals at weekly intervals. Animals in the second experimental group were used to determine the optimal duration of MK-801 treatment by administering the drug for various durations following surgery and allowing them to survive a full 8 weeks.

Animals from the first experimental group received daily injections for their entire survival period of $1-8$ weeks. For example, 1 week survival animals were hemisected, given either saline or MK-801 injections daily for 1 week, and then immediately sacrificed. Eight week animals were hemisected, received either saline or MK-801 injections for 8 weeks, and were then sacrificed. Animals in the second experimental group all received daily injections for a set duration of $1-4$ weeks, the injections were terminated, and the animals continued to survive until 8 weeks postsurgery. For example, 1 week animals were hemisected and received daily injections of either saline or MK-801 for 1 week, treatment was terminated, and the animals survived for an additional 7 weeks postsurgery. Four week animals were hemisected and received daily injections of saline or MK-801 for four weeks, treatment was terminated, and the animals survived an additional 4 weeks postsurgery. A third group of animals $(n=3)$ were used to test the long-term effects of MK-801 treatment. These animals were hemisected, received $1 \mathrm{mg} /$ $\mathrm{kg}$ MK-801 for 3 weeks, and were allowed to survive 6 months after treatment.

All animals that lost a third of their original postsurgical weight were tube-fed a liquid chocolate caloric supplement (Ensure Plus, Ross Laboratories, Columbus, $\mathrm{OH}$ ) and given a mash composed of rat pellets soaked in $30 \%$ sucrose and Nutrical (a vitamin supplement).

Tissue preparation. At the time of sacrifice all surviving animals were anesthetized with Nembutal $(75 \mathrm{mg} / \mathrm{kg}$ i.p. injection) and perfused intracardially with $0.9 \%$ saline followed by $4 \%$ paraformaldehyde in 0.1 M phosphate buffer. The midbrain and spinal cord were postfixed in situ for $1 \mathrm{hr}$, removed, and cryoprotected in $30 \%$ sucrose for $24 \mathrm{hr}$. The tissue was then frozen on dry ice, transversely sectioned on a freezing sliding microtome at $30 \mu \mathrm{m}$, and placed into phosphate-buffered saline (PBS; pH 7.4). Every third section of the magnocellular portion of the RN was stained with cresyl violet. Every fifth section of the $L_{1}$ segment of the spinal cord was stained for cresyl violet and counterstained with myelin. The myelin staining was used to visualize the boundary formed by myelinated afferent fibers surrounding $\mathrm{CN}$.

Cell quantification. Cell counts of $\mathrm{CN}$ and $\mathrm{RN}$ neurons with obvious nucleoli were made using the Bioquant Image Analysis System (Cambridge Instruments) attached to a Leitz Dialux microscope. The crosssectional area of every $\mathrm{CN}$ neuron was also measured on the Bioquant Image Analysis System at $100 \times$. The significance of differences between soma sizes for control and experimental groups was tested using a Kruskal-Wallis test. All cell counts were corrected for the probability of undetected particles utilizing soma diameter with the Hendry analysis (Smolen et al., 1983) to obtain a factor for corrected neuron counts. The Hendry analysis is a modification of the Abercrombie method (Hendry, 1976). Although the extent to which the Abercrombie correction is widely applicable has been challenged (Coggeshall, 1992), an analysis using the formula of Clarke (1992) suggests that the Hendry formula would produce a maximum error of $3.5 \%$ in our material. Mean cell numbers on the experimental side are expressed as the percentage of the contralateral undamaged side. Intraanimal differences (right side - left side) were determined with a multiple-comparison $t$ test. Differences between animal (saline treated vs MK-801 treated) cell counts were tested using the Mann-Whitney $U$ test with corrections for multiple comparisons $(p<0.05)$.

\section{Results}

Comparisons of right- and left-side cell counts taken from normal animals show that there is no significant difference in neuron number between right and left $\mathrm{CN}$ or right and left RN (Table 1). There is also no significant difference in cell numbers between normal nuclei and the contralateral or undamaged nuclei in $\mathrm{CN}$ or RN of experimental rats. Cell counts from the undamaged nucleus are therefore used as an internal control to cell counts from the lesioned side. 


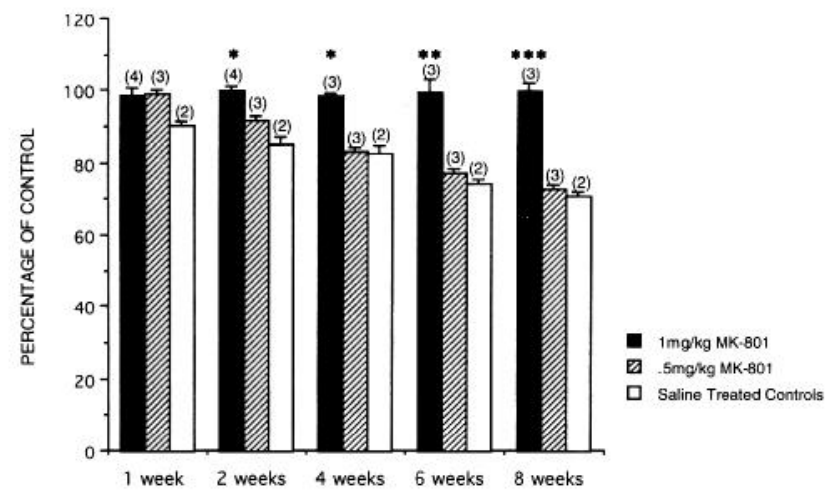

A

POST-OPERATIVE SURVIVAL PERIODS
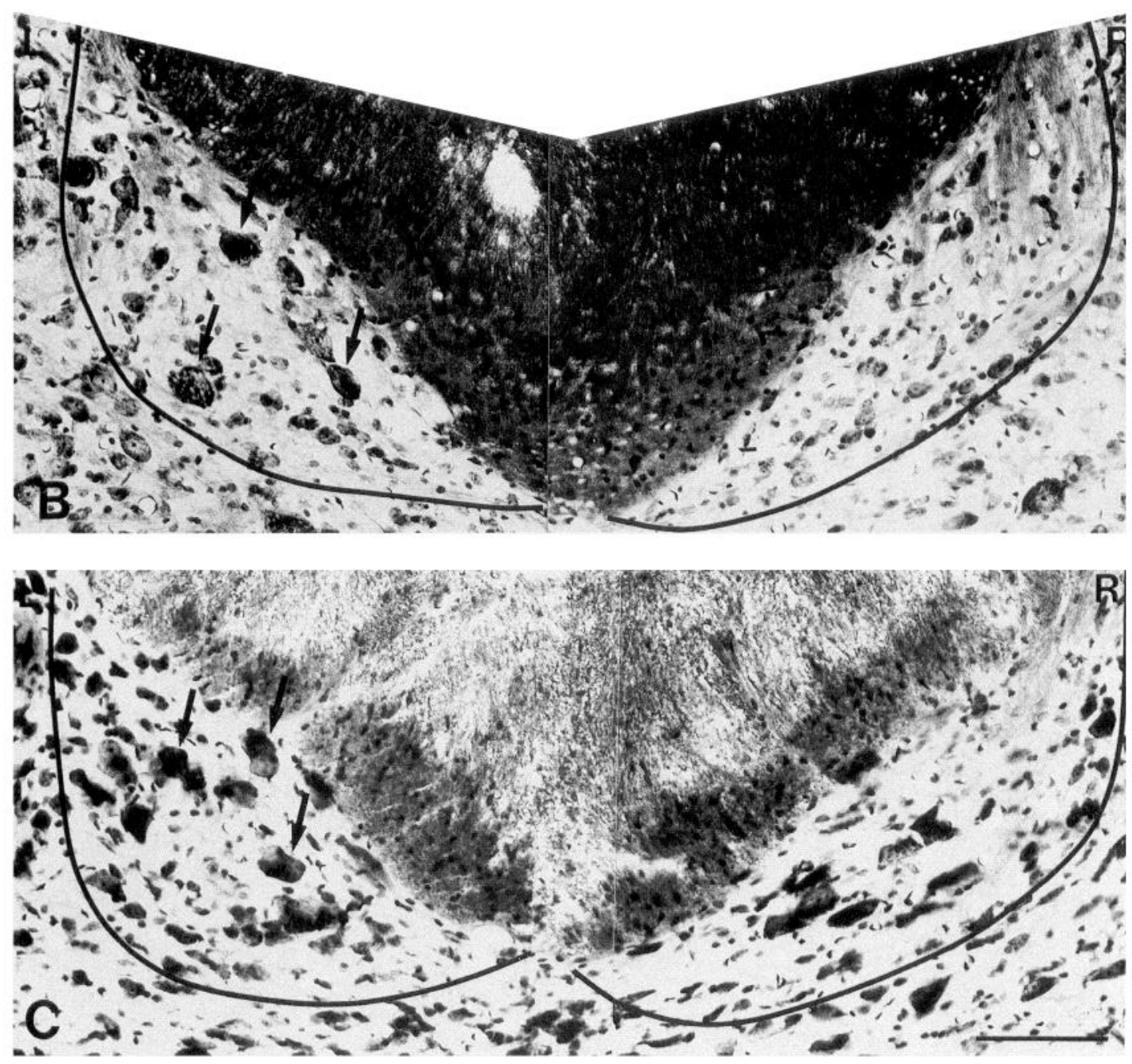

Figure 1. A, MK-801 administration (1 mg/kg) inhibits axotomy-induced cell death of $\mathrm{CN}$ neurons, and the rescue is dose dependent. All bars represent means of L:R ratio + SEM. Saline control animals (open bars) begin showing cell death by the first week increasing to $30 \%$ by 8 weeks. Animals that received daily injections of $1 \mathrm{mg} / \mathrm{kg}$ MK-801 (solid bars) exhibited virtually no cell loss at any survival period. By 2 weeks, cell survival in $1 \mathrm{mg} / \mathrm{kg}$-treated animals was significantly greater than saline-treated animals. Animals that received a daily injection of $0.5 \mathrm{mg} / \mathrm{kg} \mathrm{MK}-$ 801 (hatched bars) begin showing cell loss by the second week and by the fourth week cell death parallels that seen in operated control animals $(*$, $\left.p<0.05 ;{ }^{* *}, p<0.01 ;{ }^{* * *}, p<0.001\right)$. B, Photomicrograph of Clarke's nucleus at $\mathrm{L}_{1}$ in an operated control rat that received daily injections of saline for 8 weeks. Arrows indicate various large projection neurons present in the unoperated $(L)$ side. The line identifies the borders of the nuclei; note the absence of most large neurons from the experimental $(R)$ nucleus. $C$, Photomicrograph of Clarke's nucleus labeled with cresyl violet at $\mathrm{L}_{1}$ in a rat that received $1 \mathrm{mg} / \mathrm{kg}$ MK- 801 for 8 weeks and then was sacrificed. The line identifies Clarke's nuclei; the $R$, nucleus that is the experimental side; and arrows indicate various $\mathrm{CN}$ neurons. Scale bar, $50 \mu \mathrm{m}$. 
Time and dose requirements to prevent death of axotomized neurons (first experimental group)

Clarke's nucleus. In the first experimental group of animals, the rats received daily injections of either MK-801 or saline for their entire survival period of from 1 to 8 weeks. As shown in Figure $1 A$, axotomized animals that are saline treated progressively lose $30 \%$ of their CN neurons by 8 weeks following surgery $(p<0.001)$. Cell loss in $\mathrm{CN}$ appears by 1 week after hemisection $(10 \%)$ and increases over time until by 4 weeks this loss is significant ( $p<0.05$ ), and by 8 weeks is highly significant $(30 \%$, $p<0.001$ ). This progression of $\mathrm{CN}$ cell loss over time is consistent with that observed in previous studies (Liu, 1955; Loewy and Schader, 1977; Himes et al., 1990). In contrast, there is no cell loss in animals treated with $1 \mathrm{mg} / \mathrm{kg}$ MK-801 at any time point tested.

Daily treatment with only $0.5 \mathrm{mg} / \mathrm{kg}$ MK-801 delays, but does not prevent, axotomy-induced cell death of $\mathrm{CN}$ neurons. The animals that receive this lower dosage show a slight effect of treatment at 2 weeks ( $8 \%$ cell loss), but by 4 weeks the cell loss is similar to saline-treated animals and significantly greater than $1 \mathrm{mg} / \mathrm{kg}$-treated animals $(p<0.001)$.

Red nucleus. The saline-treated animals also show significant cell loss in the RN by 8 weeks (Fig. 2). After 1 week there is a $3 \%$ cell loss that increases to $22 \%(p<0.01)$ by 8 weeks. RN cell loss of $22 \%$ or greater by 8 weeks has been confirmed in other studies investigating the effect of RST transection (Prendergast and Stelzner, 1976; Egan et al., 1977; Goshgarian et al., 1983; Feringa et al., 1988; Xu and Martin, 1990). Daily administration of $1 \mathrm{mg} / \mathrm{kg} \mathrm{MK}-801$ prevents axotomy-induced cell death of RN neurons at all time periods tested. The difference between animals treated with $1 \mathrm{mg} / \mathrm{kg} \mathrm{MK}-801$ and salinetreated animals is significant by 6 weeks $(p<0.05)$ and highly significant by 8 weeks $(p<0.01)$. Administration of $0.5 \mathrm{mg} / \mathrm{kg}$ MK-801 does not result in a statistically significant increase in surviving neurons at any survival time although there is clearly a trend for increased cell numbers at all time points.

\section{Duration of administration required to prevent death of axotomized neurons (second experimental group)}

Clarkes nucleus. In the second experimental group of animals we determined the effects of restricting administration of MK801 for the first 1--4 weeks of an 8 week survival period. Treatment with $1 \mathrm{mg} / \mathrm{kg} \mathrm{MK-801} \mathrm{for} \mathrm{the} \mathrm{first} 3$ weeks is as effective at preventing axotomy-induced cell death in $\mathrm{CN}$ as treatment for the entire 8 weeks (Fig. 3A). A surprising finding is that treatment of animals with $1 \mathrm{mg} / \mathrm{kg} \mathrm{MK}-801$ for only 1 week markedly increases the number of $\mathrm{CN}$ cells that die (92\% over what is expected after axotomy alone). Since approximately $70 \%$ of $\mathrm{CN}$ neurons are axotomized at $\mathrm{T}_{9}$ in the cat (Sanncr and Goldberger, 1989), it may be that both $\mathrm{CN}$ interneurons and projecting neurons are vulnerable to the limited treatment with MK-801. Animals that receive $0.5 \mathrm{mg} / \mathrm{kg}$ MK-801 treatment also showed a slight exaggeration of cell loss (12\%) when treatment is withdrawn after 1 week, but this loss is not statistically different from that which occurs after saline treatment. Continued administration of $0.5 \mathrm{mg} / \mathrm{kg}$ MK-801 for the remaining 24 weeks does not prevent axotomy-induced cell death.

Red nucleus. The duration of administration of MK-801 required to prevent RN neuron cell loss is less than required by $\mathrm{CN}$ neurons. Two weeks of $1 \mathrm{mg} / \mathrm{kg} \mathrm{MK}-801$ treatment is sufficient to permanently rescue all RN neurons (Fig. 4). With-

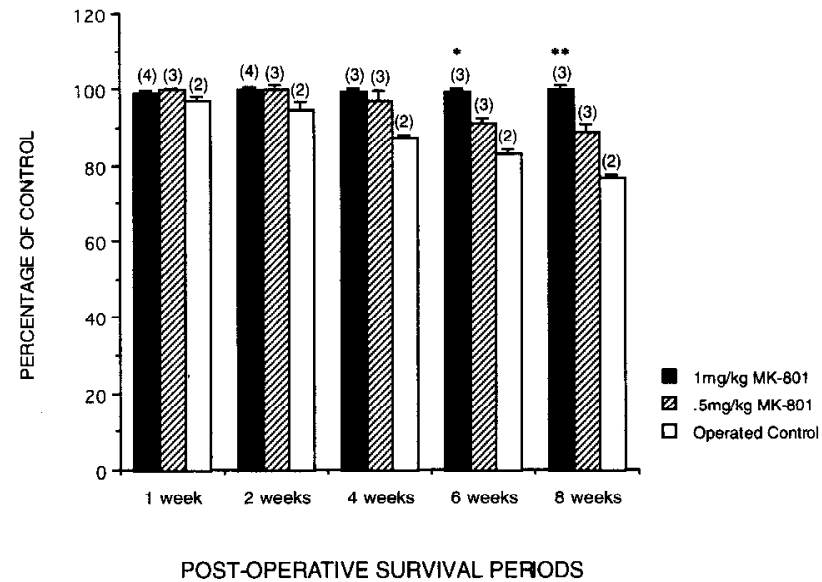

Figure 2. MK-801 prevents axotomy-induced cell death of RN neurons, and the effect is dose dependent. All bars represent the means of L:R ratios + SEM. Operated control animals (open bars) show approximately $22 \%$ cell loss by 8 weeks. Animals that received $1 \mathrm{mg} / \mathrm{kg}$ MK801 daily (solid bars) show no cell loss after any survival period. By 6 weeks cell survival is significantly greater than in saline-treated animals $\left.{ }^{*}, p<0.05{ }^{* *}, p<0.01\right)$. When compared to the operated control, the $0.5 \mathrm{mg} / \mathrm{kg} \mathrm{MK}-801$ (hatched bars) treatment was only able to inhibit approximately $11 \%$ of axotomy-induced cell death in the RN by 8 weeks. This result was not significant.

drawal of $1 \mathrm{mg} / \mathrm{kg} \mathrm{MK}-801$ treatment after 1 week also increases cell loss in RN over that predicted by axotomy alone $(p<0.01)$, but the effect is less pronounced than in CN as cell loss is only increased by $37 \%$. Treatment with $0.5 \mathrm{mg} / \mathrm{kg} \mathrm{MK}-801$ has no protective effect.

Limited treatment with MK-801 appears to provide a permanent protective effect in both $\mathrm{CN}$ and $\mathrm{RN}$. Three rats treated with MK-801 for 3 weeks, but allowed to survive for 6 months, showed no cell loss in either nucleus.

\section{Effects of treatment on soma size in Clarke's nucleus}

The mean soma size of CN neurons in the control, undamaged nuclei of all experimental animals did not significantly differ from normals $(p>0.05)$. Therefore, the soma size of axotomized neurons was compared with the soma size of control neurons.

In group 1, where treatment periods equal survival times, the mean soma sizes for $1 \mathrm{mg} / \mathrm{kg} \mathrm{MK}-801$-treated animals did not differ from normals for any time periods tested (Table $2 ; p>$ $0.05)$. This is in contrast to saline-treated and $0.5 \mathrm{mg} / \mathrm{kg} \mathrm{MK}$ 801-treated animals, which both showed similar significant decreases in mean soma area as the treatment period increased. Therefore, continued treatment with $1 \mathrm{mg} / \mathrm{kg}$ MK-801 inhibits not only axotomy-induced cell loss in $\mathrm{CN}$, but any shrinkage of mcan soma arca as wcll.

In group 2, where the survival time is 8 weeks and the treatment periods vary from 1 to 4 weeks postsurgery, the mean soma area for all experimental nuclei decrease significantly from normal (Table 2). Even though treatment with $1 \mathrm{mg} / \mathrm{kg} \mathrm{MK}$ 801 for 3 weeks or more rescues all axotomized CN neurons, it is unable to maintain normal mean soma area. Area measurements from animals treated for 3 weeks with $1 \mathrm{mg} / \mathrm{kg} \mathrm{MK}$ 801 show that rescued neurons now have a mean soma area similar to surviving cells in saline-treated animals.

Mortality and morbidity associated with MK-801 treatment. Thirty percent of the MK- 801 treated animals died during treatment and were not used in this study. The greatest morbidity 


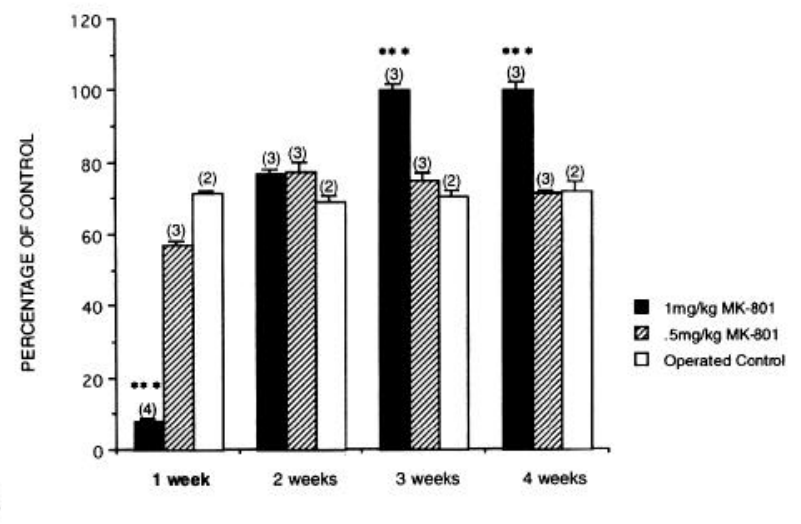

DURATION OF ADMINISTRATION
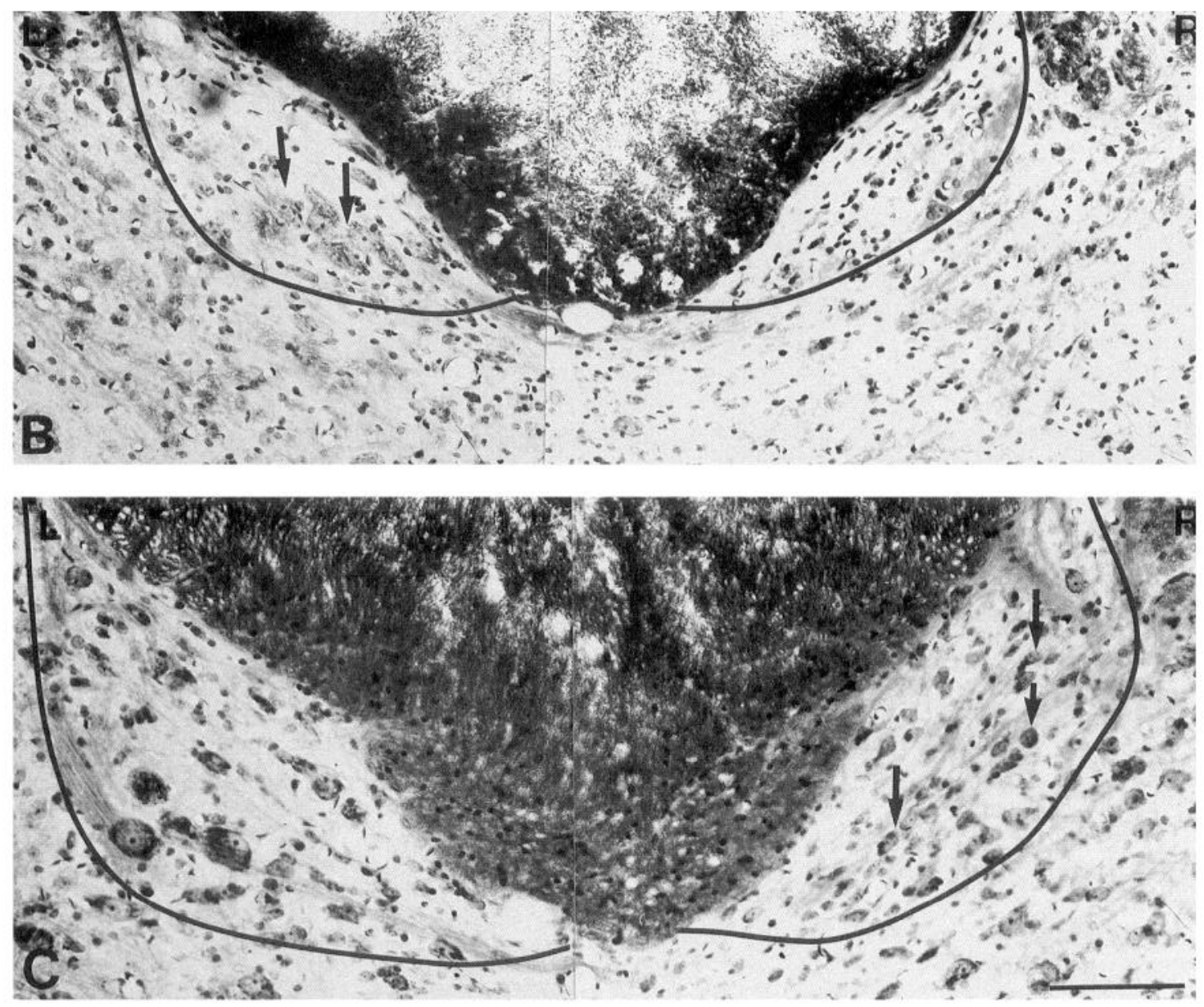

Figure 3. A, Effect of MK-801 on survival of axotomized CN neurons is time dependent. Administration of $1 \mathrm{mg} / \mathrm{kg} \mathrm{MK}-801 \mathrm{for} 1 \mathrm{week}$ increases axotomy-induced cell death while more prolonged administration rescues all neurons. These animals received daily injections for $1-4$ weeks of an 8 week survival period. At 8 weeks saline-treated animals (open bars) demonstrate a $29 \%$ cell loss. Animals that were treated with $1 \mathrm{mg} / \mathrm{kg} \mathrm{MK-}$ 801 (solid bars) for the first week of an 8 week survival period show $92 \%$ cell loss, a $68 \%$ increase in cell loss over that found in saline-treated controls $\left.{ }^{* * *}, p<0.001\right)$. However, if animals received MK-801 daily for at least the first 3 weeks of the 8 week survival period, all axotomized $\mathrm{CN}$ neurons were rescued $\left({ }^{* * *}, p<0.001\right.$ ). Animals that received $0.5 \mathrm{mg} / \mathrm{kg}$ MK- 801 (hatched bars) showed only a $12 \%$ increase in CN cell loss when treatment was withdrawn after 1 week. Continued administration of $0.5 \mathrm{mg} / \mathrm{kg} \mathrm{MK}-801$ for the remaining three time points (2 weeks, 3 weeks, or 4 weeks) did not rescue any axotomized $\mathrm{CN}$ neurons. $B$, Photomicrograph of Clarke's nucleus stained with cresyl violet, at $\mathrm{L}_{1}$ in a rat that received an injection of $1 \mathrm{mg} / \mathrm{kg} \mathrm{MK}-801$ daily for 1 week and survived an additional 7 weeks following axotomy. The line identifies the boundary of Clarke's nuclei, the $R$ is the experimental side. Note the decrease in the nucleus size as well as the lack of stained neurons; arrows indicate $\mathrm{CN}$ neurons on the left $(L)$ side. $C$, Photomicrograph of Clarke's nucleus stained with cresyl violet at $\mathrm{L}_{1}$ in a rat that received an injection of $1 \mathrm{mg} / \mathrm{kg} \mathrm{MK}-801$ daily for the first 3 weeks of an 8 week survival period following axotomy. The line identifies the boundary of Clarke's nucleus. On the experimental side $(R)$, arrows indicate $\mathrm{CN}$ neurons. Scale bar, $50 \mu \mathrm{m}$. 
occurs in animals with prolonged treatment periods (4 weeks and longer). However, all animals treated with $1 \mathrm{mg} / \mathrm{kg} \mathrm{MK}$ 801 show some symptoms, including a rapid decline in weight, dehydration, failure to groom, lack of hair growth over the incision, and aggression. Importantly, in those groups where treatment is withdrawn, whether withdrawal leads to exaggerated cell death (1 week) or complete rescue (2-3 weeks), the animals regained normal behavior and appearance.

\section{Discussion}

\section{Receptor blockade over time}

The results of this study demonstrate that axotomy-induced retrograde cell death of both $\mathrm{CN}$ and $\mathrm{RN}$ neurons is prevented by daily administration of the NMDA receptor antagonist MK801. This suggests that activation of the NMDA subtype of glutamate receptor contributes to axotomy-induced retrograde cell death in these nuclei. Excitotoxic cell death occurs in response to a variety of insults (Bowyer, 1982; Collins and Olney, 1982; Simon et al., 1984; Wieloch, 1985; Weiss et al., 1986; Croucher et al., 1988; Faden and Simon, 1988; Faden et al., 1988; Gilbert, 1988; Clifford et al., 1989; Monyer et al., 1989; Tecoma et al., 1989). In most cases this type of cell death is associated with NMDA receptors located in the immediate vicinity of the CNS lesion. Our study suggests that axotomy at some distance from the cell body may also induce vulnerability to NMDA-mediated excitotoxic effects and contribute to retrograde degeneration.

\section{Excitotoxic cell death after axotomy}

Several events that are reported to occur after axotomy would support an excitotoxic mechanism of retrograde neuron death. Neurons will spontaneously depolarize after damage to their axons (Titmus and Faber, 1990), and increased depolarization initiates several events that may lead to cell death (MacDermott et al., 1986; Nicholls and Attwell, 1990; Siesjo et al., 1991). Importantly in the present context, depolarization has been shown to be necessary for NMDA-mediated neurotoxicity (Vornov and Coyle, 1991). Furthermore, exogenous concentrations of excitatory amino acids, including glutamate, will increase dramatically following axotomy (Faden et al., 1989; Liu et al., 1991). Glutamate levels are normally regulated by uptake mechanisms located on both glia and neurons (Nicolls and Attwell,

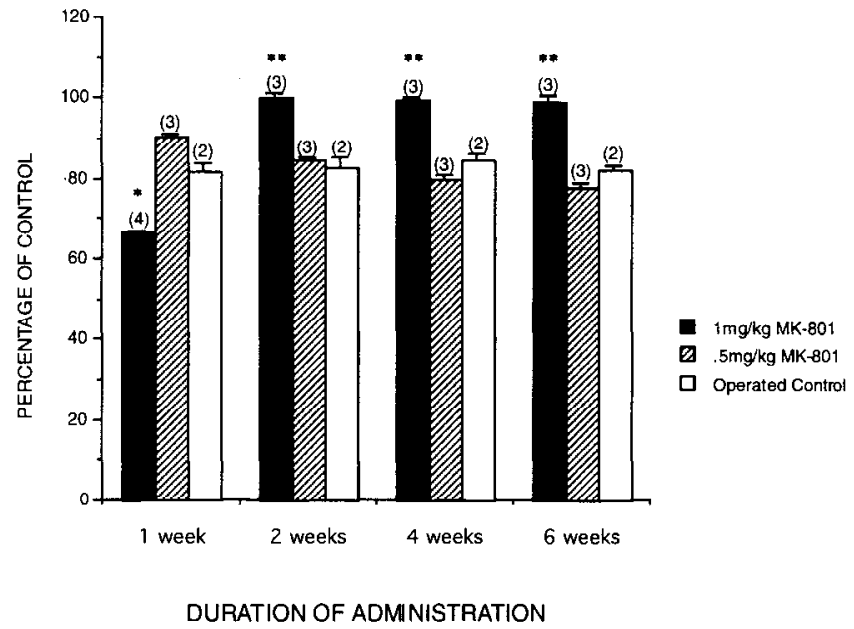

Figure 4. The effect of MK-801 on survival of axotomized RN neurons is also time dependent. Operated control animals (open bars) have approximately a $22 \%$ cell loss after an 8 week survival. Animals that received daily injections of $1 \mathrm{mg} / \mathrm{kg} \mathrm{MK}-801$ for the first week of an 8 week survival period show approximately $35 \%$ cell loss. This enhanced cell loss is not as extreme as that found in Clarke's nucleus neurons (an increase of $37 \%$ over saline treated), but it is significant $\left(^{*}, p<0.05\right)$. If the red nucleus has an extreme sensitivity period similar to that observed for Clarke's nucleus, it falls in earlier time periods than were tested in this study. When $1 \mathrm{mg} / \mathrm{kg} \mathrm{MK}-801$ is administered for at least the first 2 weeks of the survival period, there is maximum cell survival $\left({ }^{* *}, p<0.01\right)$. Administration of $0.5 \mathrm{mg} / \mathrm{kg} \mathrm{MK}-801$ for any of the set treatment periods has no significant effect on either enhancing or preventing RN cell death.

1990; Garthwaite et al., 1992), but these uptake mechanisms may be compromised after axotomy and subsequent depolarization.

It should be noted, however, that axotomy-induced increases in extracellular glutamate concentrations have only been demonstrated in the vicinity of the lesion (Faden et al., 1989; Liu et al., 1991) and may not exert a strong enough influence to trigger a neurotoxic cascade at distances from the lesion. It is possible, however, that following axotomy the membrane properties of the entire neuron may be modified resulting in an increase in the NMDA receptor's sensitivity, or even in the sensitivity of the neuron to the concentration of specific ions.

Table 2. Means of $C N$ neuron soma size $\left(\mu \mathrm{m}^{2}\right)$ at $\mathrm{L}_{1}$ from all unoperated (Normal), saline-treated (Saline), $1 \mathrm{mg} / \mathrm{kg}(1 \mathrm{MG})$, and $0.5 \mathrm{mg} / \mathrm{kg}$ (0.5MG) treated rats, \pm SEM

\begin{tabular}{|c|c|c|c|c|c|c|c|c|}
\hline \multirow{2}{*}{$\begin{array}{l}\text { Treat- } \\
\text { ment } \\
\text { period } \\
\text { (weeks) }\end{array}$} & \multicolumn{2}{|l|}{ Normal } & \multicolumn{2}{|l|}{ Saline } & \multicolumn{2}{|l|}{$1 \mathrm{MG}$} & \multicolumn{2}{|l|}{$0.5 \mathrm{MG}$} \\
\hline & Experimental & Control & Experimental & Control & Experimental & Control & Experimental & Control \\
\hline \multicolumn{9}{|c|}{ 1st experiment } \\
\hline 1 & $448.3 \pm 19.2$ & $445.9 \pm 17.6$ & $401.7 \pm 8.6$ & $451.6 \pm 15.1$ & $439.7+20.4$ & $443.9+17.2$ & $444.8 \pm 15.8$ & $455.2 \pm 13.6$ \\
\hline 2 & $453.1 \pm 15.9$ & $449.4 \pm 21.3$ & $351.7 \pm 6.4^{*}$ & $448.5 \pm 16.9$ & $454.4 \pm 17.8$ & $445.9 \pm 16.3$ & $438.6 \pm 12.3$ & $450.7 \pm 17.7$ \\
\hline 4 & $441.9 \pm 19.6$ & $446.6 \pm 16.6$ & $303.3 \pm 9.4^{*}$ & $437.9 \pm 21.3$ & $450.7 \pm 20.4$ & $455.7 \pm 14.3$ & $366.8 \pm 16.6^{*}$ & $448.9 \pm 14.1$ \\
\hline 6 & $438.7 \pm 21.7$ & $441.3 \pm 18.9$ & $274.1 \pm 7.1^{* *}$ & $454.6 \pm 14.5$ & $446.4 \pm 14.8$ & $440.0 \pm 17.7$ & $295.3 \pm 12.9^{* *}$ & $444.3 \pm 19.5$ \\
\hline 8 & $458.1 \pm 15.2$ & $449.8 \pm 12.5$ & $206.4 \pm 5.2^{* * *}$ & $447.7 \pm 16.7$ & $455.3 \pm 17.7$ & $451.9 \pm 15.8$ & $251.4 \pm 10.8^{* * *}$ & $453.8 \pm 15.3$ \\
\hline \multicolumn{9}{|c|}{ 2nd experiment } \\
\hline 1 & & & $210.9 \pm 7.3^{* * * *}$ & $459.1 \pm 15.4$ & $87.3 \pm 6.4^{* * *}$ & $437.6 \pm 19.4$ & $221.6 \pm 10.4^{* * *}$ & $458.2 \pm 15.6$ \\
\hline 2 & & & $199.6 \pm 6.6^{* * * *}$ & $447.8 \pm 17.1$ & $194.2 \pm 7.2^{* * * *}$ & $441.9 \pm 24.3$ & $215.3 \pm 11.3^{* * *}$ & $440.1 \pm 17.3$ \\
\hline 3 & & & $215.5 \pm 11.9^{* * *}$ & $441.6 \pm 16.5$ & $203.7 \pm 11.4^{* * * *}$ & $456.4 \pm 16.8$ & $209.3 \pm 8.8^{* * *}$ & $448.8 \pm 15.7$ \\
\hline 4 & & & $208.9 \pm 14.1^{* * *}$ & $454.3 \pm 24.1$ & $212.5 \pm 15.1^{* * *}$ & $440.3 \pm 17.9$ & $201.9 \pm 11.9^{* * *}$ & $451.6 \pm 13.8$ \\
\hline
\end{tabular}




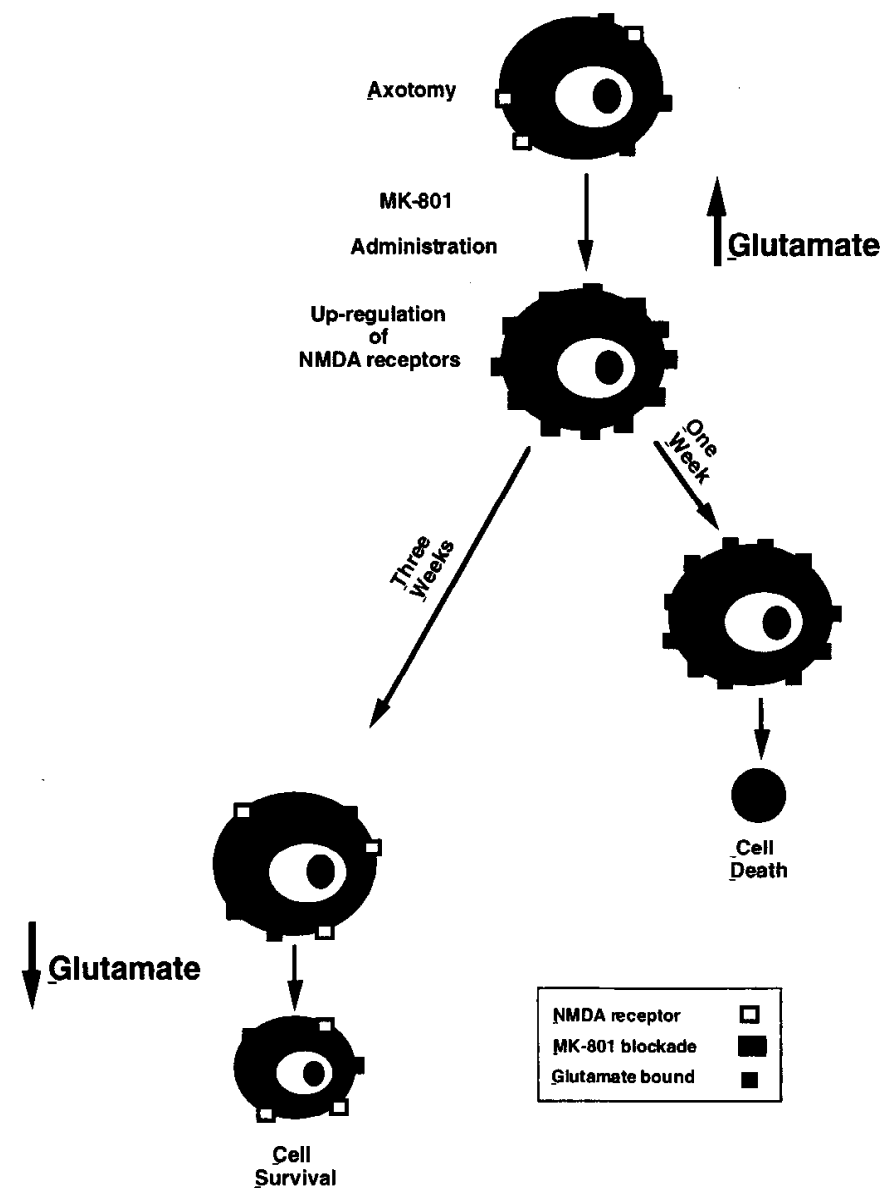

Figure 5. Diagram of suggested events that may explain exaggerated neuron death or neuron survival after administration of MK-801 to axotomized neurons for 1 or 3 weeks, respectively. Receptor blockade by MK-801 protects axotomized neurons from the elevated glutamate levels that follow axotomy. Receptor blockade also induces an upregulation of NMDA receptors. If the drug is withdrawn after only 1 week the elevated levels of excitatory amino acids and receptors result in increased toxicity to the neurons. When MK-801 is withdrawn after 3 weeks the number of NMDA receptors have downregulated in response to prolonged receptor blockade so the neurons are less vulnerable to endogenous glutamate.

Even a modest increase in membrane depolarization has been found to increase the sensitivity of the NMDA receptor, allowing the channel portion of the receptor to remain permeable to ions for longer periods (Sombati et al., 1991).

One way that axotomy may both disrupt glutamate uptake mechanisms and modify membrane properties is simply through a disruption of mitochondrial energy metabolism (Beal, 1992). Mitochondria are essential for maintaining the normal voltage gradient across the cell membrane as well as a number of processes controlling levels of intracellular calcium concentration (Blaustein, 1988). An axotomy-induced impairment of the mitochondrial electron transport chain would effect cellular levels of ATP. An interference with ATP function would in turn depolarize the cell membrane relieving the $\mathrm{Mg}^{2+}$ block within the channel portion of the NMDA receptor, allowing a greater influx of calcium into the cell (Novelli et al., 1988). A decrease in ATP would also influence the ATP-dependent extrusion of calcium from the cell, as well as the ATP high-affinity reuptake of glutamate by glia (Naito and Ueda, 1983).

\section{Receptor blockade and neuron survival}

When MK-801 is administered at a dosage of $1 \mathrm{mg} / \mathrm{kg}$ body weight for at least 3 weeks for $\mathrm{CN}$ neurons and 2 weeks for RN neurons, there is a permanent rescue of axotomized neurons. Interestingly, MK-801 administered for only the first week of an 8 week survival period produces greater cell loss in both nuclei than would occur after axotomy alone. One explanation for this phenomenon may be upregulation of NMDA receptors, making the axotomized neurons more vulnerable to endogenous glutamate. Neurons have been shown to respond to the removal of a neurotransmitter by upregulating the number of receptors that usually bind with the transmitter (Brady et al., 1989; Barkai et al., 1990; Rothman et al., 1990; Chalmers, 1991). Such upregulation has been reported after blocking the NMDA receptor. Application of AP5, a competitive NMDA antagonist, induces a $40-80 \%$ increase in ${ }^{125} \mathrm{I}-\mathrm{MK}-801$ binding in cultured cortical neurons (Williams et al., 1992). In neonatal rats, administration of $1 \mathrm{mg} / \mathrm{kg} \mathrm{MK}-801$ produces a $30-50 \%$ increase in ${ }^{3} \mathrm{H}$-glutamate binding at NMDA preferring recognition sites (McDonald et al., 1990). It is therefore possible that 1 week of receptor blockade with MK-801 upregulates the number of NMDA receptors and thereby increases the toxicity of endogenous glutamate (Fig. 5).

The fact that $1 \mathrm{mg} / \mathrm{kg} \mathrm{MK}-801$ can be withdrawn after 2 (RN) or $3(\mathrm{CN})$ weeks with a permanent prevention of axotomyinduced cell death may also be explained by receptor plasticity after the more prolonged administration. It is possible that in this 2-3 wcek period the neurons downregulate the number of NMDA receptors so that endogenous glutamate is no longer lethal. Endogenous glutamate may still be somewhat toxic, however, as evidenced by the shrinkage of cells in CN. In addition, the axotomy-induced increase in extracellular glutamate may subside in the 2-3 weeks following the lesion (Potashner and Dymczyk, 1986; Faden et al., 1989). A reduction in glutamate would cause a decrease in both depolarization and ion flux through the NMDA receptor. A decrease in intracellular calcium concentrations is especially relevant because apoptotic and necrotic cell death are both influenced by intracellular calcium concentrations (Koh and Cotman, 1992). It is also possible that prolonged blockade of the NMDA receptor enables the neuron to reestablish a calcium homeostasis so that the neuron's sensitivity to excitatory input is diminished.

\section{Comparison of $R N$ and $C N$}

The difference in the amount of cell death between $\mathrm{CN}$ and RN neurons both after axotomy and after early withdrawal of MK801 blockade may be due to several factors. One possibility is that the amount of glutamatergic input to $R N$ neurons is less than to $\mathrm{CN}$ neurons. For example, the $\mathrm{RN}$ receives a significant proportion of nonglutamatergic afferents (Nieoullon et al., 1988), while $\mathrm{CN}$ neurons are dominated by dorsal root afferents that are glutamatergic (Maxwell et al., 1990). Another possibility suggested by the present results is that target contact and availability of target derived trophic factors is protective against endogenous excitotoxic input (see Schumacher et al., 1992). Therefore, RN neurons that have collaterals to several alternative targets that survive the lesion may be less vulnerable to excitotoxic input. In fact, efferent projections arising from the RN have a number of destinations. These fibers project to the ipsilateral inferior olive as well as cross the midline (RST) to descend to contralateral interneurons and motor neurons of the 
spinal cord (Holslege and Tan, 1988). As the RST descends to the contralateral spinal cord it sends off collaterals that innervate several brainstem nuclei (Holslege and Tan, 1988). These RN targets are not axotomized by a hemiscetion at $T_{9}$ in the rat spinal cord. In contrast, $\mathrm{CN}$ neurons appear to have few or no sustaining collaterals (Walmsley, 1991) and therefore no alternative source for target contacts.

The results from this study indicate that $1 \mathrm{mg} / \mathrm{kg}$ body weight MK-801 will prevent the cell death of all axotomized $\mathrm{CN}$ and RN neurons destined to die. This implies that abnormal activation of the NMDA subtype of glutamate receptor influences the extent of retrograde cell death after axotomy. This protective effect, however, is time dependent as early withdrawal of NMDA blockade leads to cell loss greater than is normally induced by axotomy alone. Furthermore, both the protective effects and the duration of administration of NMDA receptor blockade may be important when considering therapeutic strategies aimed at promoting recovery of function after CNS injury (Albers et al., 1989).

\section{References}

Albers GW, Goldberg MP, Choi DW (1989) $N$-methyl-D-aspartate antagonists: ready for clinical trail in brain ischemia? Ann Neurol 25: $398-403$.

Barbour B, Brew II, Attwell D (1988) Electrogenic glutamate uptake in glial cells is activated by intracellular potassium. Nature $355: 433-$ 435.

Barkai A, Durkin M, Nelson HD (1990) Localized alterations of dopamine receptor binding in rat brain by repeated electroconvulsive shock: an autoradiographic study. Brain Res 529:208-213.

Baudry M, Lynch G (1985) Regulation of calcium transport in rat hippocampal mitochondria during development and following denervation. Prog Brain Res 63:107-119.

Beal FM (1992) Does impairment of energy metabolism result in excitotoxic neuroal death in neurodegenerative illnesses? Ann Neurol 31:119-130.

Benson CG, Chase MC, Potashner SJ (1991) Decreased release of D-aspartate in the guinea pig spinal cord after lesion of the red nucleus. J Neurochem 56:1174-1183.

Bernays RL, Heeb L, Cuenod M, Streit P (1988) Afferents to the rat red nucleus studied by means of $D-\left[{ }^{3} \mathrm{H}\right]$ aspartate, $\left[{ }^{3} \mathrm{H}\right]$ choline and non-selective tracers. Neuroscience 26:601-619.

Brady L, Herkenham M, Long JB, Rothman RB (1989) Chronic morphine increases $\mu$-opiate receptor binding in rat brain: a quantitative autoradiographic study. Brain Res 477:382-386.

Chalmers D, McCulloch (1991) Selective alterations in glutamate receptor subtypes after unilateral orbital enucleation. Brain Res 540: 255-265.

Clarke PGH (1992) How inaccurate is the Abercrombie correction factor for counts? Trends Neurosci 15:211-212.

Clifford DB, Zorumski CF, Olney JW (1989) Ketamine and MK-801 prevent degeneration of thalamic neurons induced by focal cortical seizures. Exp Neurol 105:272-279.

Coggeshall RE (1992) A consideration of neuronal counting methods. Trends Neurosci 15:9-13.

Collins RC, Olney JW (1982) Focal cortical seizures cause distant thalamic lesions. Science 218:177-179.

Croucher MJ, Bradford HF, Sunter DC, Watkins JC (1988) Inhibition of the development of electrical kindling of the prepyriform cortex by daily focal injections of excitatory amino acid antagonists. Eur $\mathbf{J}$ Pharmacol 152:29-38.

Egan DA, Flumerfelt BA, Gwyn DG (1977) A light and electron microscopic study of axon reaction in the red nucleus of the rat following cervical and thoracic lesions. Neuropathol Appl Neurobiol 3:423439.

Eidelberg E, Straehley D, Erspamer R, Watkins CJ (1977) Relationship between residual hind-limb-assisted locomotion and surviving axons after incomplete spinal cord injuries. Exp Neurol 56:312-322.

Faden AI, Simon RP (1988) A potential role for excitotoxins in the pathophysiology of spinal cord injury. Ann Neurol 23:623-626.

Faden AI, Lemke M, Simon RP, Noble LJ (1988) $N$-methyl-D-as- partate antagonist MK-801 improves outcome following traumatic spinal cord injury in rats: behavior, anatomic and neurochemical studies. J Neurotrauma 5:33-45.

Faden AI, Demediuk P, Panter S, Vink R (1989) The role of excitatory amino acids and NMDA receptors in traumatic brain injury. Science 244:798-800.

Feringa ER, McBride RL, Pruitt JN II (1988) Loss of neurons in the red nucleus after spinal cord transection. Exp Neurol 100:112-120.

Garthwaite G, Williams GD, Garthwaite J (1992) Glutamate toxicity: an experimental and theoretical analysis. Eur $J$ Neurosci 4:353-360.

Gilbert ME (1988) The NMDA-receptor antagonist MK-801 suppresses limbic kindling and kindled seizures. Brain Res 463:90-99.

Goldberger ME (1980) Motor recovery after lesions. Trends Neurosci: 288-291.

Gomez-Pinilla F, Tram H, Cotman CW, Nieto-Sampedro M (1989) Neuroprotective effect of MK-801 and U-TO488H after contusive spinal cord injury. Exp Neurol 104:118-124.

Goshgarian HG, Koistinen JM, Schmidt ER (1983) Cell death and changes in the retrograde transport of horseradish peroxidase in rubrospinal neurons following spinal cord hemisection in the adult rat. J Comp Neurol 214:251-257.

Hendry IA (1976) A method to correct adequately for the change in neuronal size when estimating neuronal numbers after nerve growth factor treatment. J Neurocytol 5:337-349.

Himes BT, Goldberger ME, Tessler A (1990) Grafts of fetal CNS tissue rescue axotomized Clarke's nucleus neurons in adult and neonatal operates. Soc Neurosci Abstr 16:341.9.

Holstege G, Tan J (1988) Projections from the red nucleus and surrounding areas to the brainstem and spinal cord in the cat. An HRP and autoradiographic tracing study. Bchav Brain Res 28:33-57.

Janssen L, Hansebout RR (1989) Pathogenesis of spinal cord injury and newer treatments. A review. Spine 14:23-32.

Kemp JA, Foster AC, Wong EHF (1987) Non-competitive antagonists of excitatory amino acid receptors. Trends Neurosci 10:294-299.

Kon J-Y, Cotman CW (1992) Programmed cell death: its possible contribution to neurotoxicity mediated by calcium channel antagonists. Brain Res 587:233-240.

Liu C (1955) Time patterns in retrograde degeneration after trauma of central nervous system of mammals. In: Regeneration in the central nervous system (Windle WF, ed), pp 84-93. Springfield, IL: Thomas.

Liu D, Thangnipon W, McAdoo DJ (1991) Excitatory amino acids rise to toxic levels upon impact injury to the rat spinal cord. Brain Res 547:344-348.

Loewy AD, Schader RE (1977) A quantitative study of retrograde neuronal changes in Clarke's column. J Comp Neurol 171:65-82.

MacDermott A, Mayer ML, Westbrook GL, Smith SJ, Barker JL (1986) NMDA-receptor activation increases cytoplasmic calcium concentration in cultured spinal cord neurones. Nature 321:519-522.

Mann MD (1973) Clarke's column and the dorsal spinocerebellar tract: a review. Brain Behav Evol 7:34-83.

Maxwell DJ, Christie WM, Ottersen OP, Storm-Mathisen J (1990) Terminals of group la primary afferent fibers in Clarke's column are enriched with L-glutamate-like immunoreactivity. Brain Res 510:346350.

Mayer ML, Miller RJ (1990) Excitatory amino acids receptors, second messengers and regulation of intracellular $\mathrm{Ca}^{2+}$ in mammalian neurons. Trends Pharmacol Sci 11:254-260.

McDonald JW, Johnston MV (1990) Physiological and pathophysiological roles of excitatory amino acids during central nervous system development. Brain Res Rev 15:41-70.

McDonald JW, Silverstein FS, Johnston MV (1990) MK-801 pretreatment enhances $N$-metheyl-D-aspartate-mediated brain injury and increases brain $N$-methyl-D-aspartate recognition site binding in rats. Neuroscience 38:103-113.

Monyer H, Goldberg MP, Choi DW (1989) Glucose deprivation neuronal injury in cortical culture. Brain Res 483:347-354.

Naito S, Ueda T (1983) Adenosine triphosphate-dependent uptake of glutamate into protein I-associated synaptic vesicles. J Biol Chem 258:696-699.

Nicolls D, Attwell D (1990) The release and uptake of excitatory amino acids. Trends Pharmacol Sci 11:462-468.

Nieoullon A, Dusticier N (1981) Decrease in choline acetyltransferase and high affinity glutamate uptake in the red nucleus of the cat after cerebellar lesion. Neurosci Lett 24:267-271.

Nieoullon A, Vuillon-Cacciuttolo G, Dusticier N, Kereian L, Andre D, Bosler O (1988) Putative neurotransmitters in the red nucleus and 
their involvement in post lesion adaptive mechanism. Behav Brain Res 28:163-174.

Novelli A, Reilly JA, Lysko PG, Henneberry R (1988) Glutamate becomes neurotoxic via the $N$-methyl-D-asparate receptor when intracellular energy levels are reduced. Brain Res 451:201-212.

Potashner SL, Dymczyk L (1986) Amino acid levels in the guinea pig spinal gray matter after axotomy of primary sensory and descending tracts. Neuroscience 47:412-422.

Prendergast J, Stelzner D (1976) Changes in the magnocellular portion of the red nucleus following thoracic hemisection in the neonatal and adult rat. J Comp Neurol 166:163-172.

Rothman R, Long JB, Bykov V, Jacobson AE, Rice KC, Holaday JW (1990) Pretreatment of rats with the irreversible $\mu$-receptor antagonist, $\beta$-FNA, fails to prevent naltrxone-induced upregulation of $\mu$-opiod receptors. Neuropharmacology 29:805-810.

Sanner CA, Murray M, Goldberger ME (1993) Removal of dorsal root afferents prevents retrograde death of axotomized Clarke's nucleus neurons in the cat. Exp Neurol 123:81-90.

Schumacher JM, Short MP, Hyman BT, Breakefield XO, Isacson O (1991) Intracerebral implantation of nerve growth factor-producing fibroblasts protects striatum against neurotoxic levels of excitatory amino acids. Neuroscience 45:561-570.

Siesjo BK, Memezawa H, Smith ML (1991) Neurocytotoxicity: pharmacological implications. Fundam Clin Pharmacol 5:755-767.

Simon RP, Swan JH, Griffiths T, Meldrum BS (1984) Blockade of $N$-methyl-D-aspartate receptors may protect against ischemic damage in the brain. Science 226:850-852.

Smolen AJ, Wright LL, Cunningham TJ (1983) Neuron numbers in the superior cervical sympathetic ganglion of the rat: a critical comparison of methods for cell counting. J Neurocytol 12:739-750.

Sombati S, Coulter DA, DeLorenzo RJ (1991) Neurotoxic activation of glutamate receptors induces an extended neuronal depolarization in cultured hippocampal neurons. Brain Res 566:316-319.

Tecoma ES, Monyer H, Goldberg MP, Choi DW (1989) Traumatic neuronal injury in vitro is attenuated by NMDA antagonists. Neuron 2:1541-1545.

Titmus M, Faber D (1990) Axotomy-induced alterations in the electrophysiological characteristics of neurons. Prog Neurobiol 35:1-51.

Vornov JJ, Coyle JT (1991) Enhancement of NMDA receptor-mediated neurotoxicity in the hippocampal slice by depolarization and ischemia. Brain Res 555:99-106.

Walmsley B (1991) Central synaptic transmission studies of the connection between, afferent fibers and dorsal spino-cerebellar tract (DSCT) neurones in Clarke's column of the spinal cord. Prog Neurobiol 36: $391-493$.

Weiss JH, Goldberg MP, Choi DW (1986) Ketamine protects cultured neocortical neurons from hypoxic injury. Brain Res 380:186-190.

Wieloch R (1985) Hypoglycemia-induced neuronal damage prevented by a $N$-methyl-D-aspartate antagonist. Science 230:681-683.

Willetts J, Balster RL, Leander JD (1990) The behavioral pharmacology of NMDA receptor antagonists. Trends Pharmacol Sci 11:423428.

Williams K, Dichter MA, Molinoff PB (1992) Up-regulation of $N$-methyl-D-aspartate receptors on cultured cortical neurons after exposure to antagonists. Mol Pharmacol 42:147-151.

Wong EHF, Kemp JA, Preistly T, Knight AR, Woodruff GN, Iverson LL (1986) The anticonvulsant MK-801 is a potent $N$-methyl-Dasparate antagonist. Proc Natl Acad Sci USA 83:7104-7108.

Xu Q, Martin GF (1990) The response of rubrospinal neurons to axotomy in the adult opossum, Didelphis virginiana. Exp Neurol 108: 46-54. 